\title{
A picture is worth a thousand words: the application of camera trapping to the study of birds
}

\author{
TIMOTHY G. O'BRIEN and MARGARET F. KINNAIRD
}

\section{Summary}

This study reviews the use of remotely triggered still cameras, known as camera traps, in bird research and suggests new methods useful for analyzing camera trap data. Camera trapping may be most appropriate for large, ground-dwelling birds, such as cracids and pheasants. Recent applications include documentation of occurrence of rare species and new species records, nest predation studies and behavioural studies including nest defence, frugivory, seed dispersal, and activity budgets. If bird postures are analyzed, it may be possible to develop behavioural time budgets. If birds are marked or individually identifiable, abundance may be estimated through capture-recapture methods typically used for mammals. We discourage use of relative abundance indices based on trapping effort because of the difficulty of standardizing surveys over time and space. Using the Great Argus Pheasant Argus argusianus, a cryptic, terrestrial, forest bird as an example, we illustrate applications of occupancy analysis to estimate proportion of occupied habitat and finite mixture models to estimate abundance when individual identification is not possible. These analyses are useful because they incorporate detection probabilities $<_{1}$ and covariates that affect the sample site or the observation process. Results are from camera trap surveys in the $3,568 \mathrm{~km}^{2}$ Bukit Barisan Selatan National Park, Indonesia. We confirmed that Great Argus Pheasants prefer primary forest below $500 \mathrm{~m}$. We also find a decline in occupancy $\left(6-8 \% \mathrm{yr}^{-1}\right)$. Point estimates of abundance peak in 2000, followed by a sharp decline. We discuss the effects of rarity, detection probability and sampling effort on accuracy and precision of estimates.

\section{Introduction}

In the study of rare and elusive wildlife, photographs not only provide confirmation of presence and identity, but photographic evidence may also provide insights into distribution, abundance, population dynamics and behaviour as well. Sanderson and Trolle (2005) trace the first use of a camera trap to George Shiras III, a pioneer of wildlife photography. In 1913, Shiras wrote of a newly developed camera trap that allowed an animal to trigger the camera and take a selfportrait. Camera-trapping remained largely a hobby of photographers and naturalists until the 1980s when American game hunters began using camera traps to scout favourite hunting locations and a small industry developed. In the early 1990s, Karanth (1995) began experimenting with camera traps to identify individuals and estimate the abundance of tigers Panthera tigris in the Nagarahole National Park, India. Karanth's work marks the first time that camera traps were used to sample a wildlife population in a statistically rigorous manner.

Today camera traps utilize active and passive sensors to detect animals passing through the field of view by their movements and by their body heat. They use auto-focus cameras that stamp each photograph with a time and date, and although film cameras are still widely used, 
digital cameras are rapidly becoming the standard. Some new features include infrared flashes that eliminate potential for trap shyness resulting from normal camera flash (Wegge et al. 2004) and use of digital surveillance cameras (Bolton et al. 2007) with passive sensor activation systems. Improved CMOS chip technology has reduced size and weight of cameras as well as power consumption, and new battery technology has extended the field life of camera traps before they require servicing. New camera trap are under development that use cell phone technology to make further gains in weight and power savings (L. Hunter, pers comm.). Because camera traps sit unobtrusively in the forest, they are very well suited for studies of animals that avoid humans, might be influenced by the presence of an observer, are nocturnal or are rare.

Since Karanth's work, camera-trapping has gained popularity as a tool for a wide range of ecological studies, but has focused primarily on mammals (large cats: Karanth and Nichols 1998, Karanth et al. 2004; small carnivores: DeLuca and Mpunga 2002, O'Connell et al. 2006; forest ungulates: O'Brien et al. 2003, Rovero and Marshall 2004) and behavioural studies (Griffiths and van Schaik 1993, Beck and Terborgh 2002). Because most camera surveys target mediumand large-sized mammals, traps are set at heights where birds are not reliably detected. Traps set at $0.4-0.6 \mathrm{~m}$ above the ground are often too high to detect birds close to the trap, or result in photographs focused on the background rather than the bird of interest. In spite of issues with camera positioning, camera surveys have identified nearly 100 bird species in Asia and Latin America (Table I). Camera traps are sensitive enough to detect the movement of small as well as large birds, including flycatchers, babblers and forktails (Table 1). Perhaps the greatest potential, however, is for the large, terrestrial forest birds that are often too wary to approach directly (see below). Most of the species detected in Table 1 weighed $>100 \mathrm{~g}$ and, although a large proportion are not considered ground-dwelling, it is unknown whether birds normally associated with strata above ground level can be reliably observed using camera traps. No one has yet tried to use camera trap in the trees. The use of lures, baits and decoys to attract birds to a camera trap is possible (Buckland et al. 2006) for studies of abundance, but is likely to incite behaviours (mobbing, feeding for example) which may not be desirable.

In this paper, we review recent applications of camera trapping to the study of birds and then illustrate developments in research and monitoring of terrestrial forest bird populations using data from a long-term study of Great Argus Pheasant Argus argusianus in southern Sumatra, Indonesia. The Great Argus Pheasant is an appropriate example because it represents a diverse group of large, terrestrial forest birds (pheasants, cracids, tinamous, pittas and megapodes) that we know very little about, in part due to the difficulties of observing them in the wild.

\section{Avian studies using cameras}

The simplest use of camera trapping is documentation of a species' occurrence at a site. Species occurrence data is an important component of biodiversity surveys, as well as a fundamental aspect of range determination and IUCN status. On Sumatra, Indonesia, camera trap surveys have contributed important new records for rare forest birds. In Kerenci Seblat National Park (KSNP), Denata et al. (2008) recorded the first evidence for the Critically Endangered Sumatran Ground-cuckoo Carpococcyx viridis, a species only recently re-discovered in Bukit Barisan Selatan National Park (BBSNP: Zetra et al. 2002). Martyr (1997) reported a photograph of the Giant Pitta Pitta caerulaea in KSNP, the first observation in more than a century, as well as the second sighting of the Graceful Pitta Pitta venusta in 80 years. We have used camera traps to document Giant Pittas, and three new pheasant species in BBSNP. In India Jeganathan et al. (2002) deployed camera traps to detect the rare nocturnal Jerdon's Courser Rhinoptilus bitorquatus. Unfortunately, camera trap surveys that focus on single species or mammal communities may fail to record the complete identity of birds occurring in the photographs, hindering potential new discoveries. With proper attention to detail, cameras traps can be used profitably for inventories of terrestrial birds whenever the presence of a human observer is likely to cause a flight response or cryptic response of target species. 
Table 1 . Bird species observed in camera trap photos and weight in grams. ${ }^{*}$ indicates average weight for genus, rather than species weight.

\begin{tabular}{|c|c|c|c|c|c|}
\hline Family & Genus & Species & Common name & Weight & Source \\
\hline$\overline{\text { Anatidae }}$ & Cairina & moschata & Muscovy Duck & 2,915 & 1 \\
\hline Anatidae & Neochen & jubata & Orinoco Goose & 1,250 & 1 \\
\hline Bucerotidae & Berenicornis & comatus & White-crowned Hornbill & 1,470 & 3 \\
\hline Bucerotidae & Buceros & bicornis & Great Hornbill & 2,680 & 1 \\
\hline Bucerotidae & Buceros & rhinoceros & Rhinoceros Hornbill & 2,380 & 5 \\
\hline Glareolidae & Rhinoptilus & bitorquatus & Jerdon's Courser & $131^{*}$ & 7 \\
\hline Scolopacidae & Scolopax & rusticola & Eurasian Woodcock & 306 & 1 \\
\hline Ardeidae & Ardea & cinerea & Grey Heron & 1,443 & 2 \\
\hline Ardeidae & Ardeola & bacchus & Chinese Pond Heron & 253 & 1 \\
\hline Ardeidae & Bubulcus & ibis & Cattle Egret & 338 & 1 \\
\hline Ardeidae & Butorides & striatus & Striated Heron & 212 & 1 \\
\hline Ardeidae & Gorsachius & melanolophus & Malayan Night Heron & $500^{*}$ & 3 \\
\hline Ciconiidae & Ciconia & episcopus & Woolly-necked Stork & 2,185 & 1 \\
\hline Ciconiidae & Ciconia & nigra & Black Stork & 3,000 & 1 \\
\hline Ciconiidae & Ciconia & stormi & Storm's Stork & 1,850 & 3 \\
\hline Ciconiidae & Ephippiorhynchus & asiaticus & Black-necked Stork & 4,100 & 1 \\
\hline Ciconiidae & Leptoptilos & javanicus & Lesser Adjutant & 4,994 & 1 \\
\hline Threskiornithidae & Thaumatibis & gigantea & Giant Ibis & ND & 1 \\
\hline Threskiornithidae & Theristicus & caudatus & Buff-necked Ibis & 1,550 & 1 \\
\hline Columbidae & Chalcophaps & indica & Emerald Dove & 124 & 1 \\
\hline Columbidae & Ducula & aenea & Green Imperial Pigeon & 560 & 1 \\
\hline Columbidae & Leptotila & verreauxi & White-tipped Dove & 153 & 1 \\
\hline Columbidae & Treron & vernans & $\begin{array}{l}\text { Pink-necked Green } \\
\text { Pigeon }\end{array}$ & $215^{*}$ & 1 \\
\hline Alcedinidae & Actenoides & concretus & $\begin{array}{l}\text { Rufous-collared } \\
\text { Kingfisher }\end{array}$ & 74 & 5 \\
\hline Alcedinidae & Halcyon & smyrnensis & $\begin{array}{l}\text { White-throated } \\
\text { Kingfisher }\end{array}$ & 91 & 1 \\
\hline Cuculidae & Centropus & sinensis & Greater Coucal & 277 & 1 \\
\hline Cuculidae & Carpococcyx & viridis & $\begin{array}{l}\text { Sumatran } \\
\text { Ground-cuckoo }\end{array}$ & 465 & 5 \\
\hline Cuculidae & Neomorphus & radiolosus & Banded Ground-cuckoo & $340^{*}$ & 1 \\
\hline Accipitridae & Aviceda & leuphotes & Black Baza & $314^{*}$ & 1 \\
\hline Accipitridae & Buteo & Buteo & Buzzard & 81 & 2 \\
\hline Accipitridae & Buteogallus & urubitinga & Great Black Hawk & 925 & 1 \\
\hline Accipitridae & Harpagus & bidentatus & Double-toothed Kite & 182 & 1 \\
\hline Accipitridae & Spilornis & cheela & Crested Serpent Eagle & 907 & 1 \\
\hline Cathartidae & Cathartes & aura & Turkey Vulture & 1,467 & 1 \\
\hline Cathartidae & Cathartes & burrovianus & $\begin{array}{l}\text { Lesser Yellow-headed } \\
\text { Vulture }\end{array}$ & 953 & 1 \\
\hline Cathartidae & Coragyps & atratus & Black Vulture & 2,172 & 1 \\
\hline Falconidae & Caracara & cheriway & Crested Caracara & 834 & 1 \\
\hline Cracidae & Crax & fasciolata & Bare-faced Currasow & 2,515 & 1 \\
\hline Cracidae & Crax & tuberosa & Razor-billed Curassow & $3, \mathrm{OOO}^{*}$ & 1 \\
\hline Cracidae & Ortalis & canicollis & Chaco Chachalaca & 590 & 1 \\
\hline Cracidae & Penelope & jacquacu & Spixs Guan & 1,282 & 1 \\
\hline Cracidae & Pipile & pipile & Common Piping-guan & $1,250^{*}$ & 1 \\
\hline Phasianidae & Arborophila & brunneopectus & Bar-backed Partridge & 317 & 1 \\
\hline Phasianidae & Arborophila & charltonii & $\begin{array}{l}\text { Chestnut-necklaced } \\
\text { Partridge }\end{array}$ & 290 & 1 \\
\hline Phasianidae & Arborophila & rufogularis & $\begin{array}{l}\text { Rufous-throated } \\
\text { Partridge }\end{array}$ & 250 & 1 \\
\hline Phasianidae & Argusianus & $\operatorname{argus}$ & Great Argus Pheasant & 2,361 & 1 \\
\hline
\end{tabular}


Table 1. Continued.

\begin{tabular}{|c|c|c|c|c|c|}
\hline$\overline{\text { Family }}$ & Genus & Species & Common name & Weight & Source \\
\hline Phasianidae & Bambusicola & fytchii & $\begin{array}{l}\text { Mountain Bamboo- } \\
\text { partridge }\end{array}$ & 343 & 1 \\
\hline Phasianidae & Caloperdix & oculeus & Ferruginous Partridge & 190 & 5 \\
\hline Phasianidae & Francolinus & pintadeanus & Chinese Francolin & 368 & 1 \\
\hline Phasianidae & Gallus & gallus & Red Junglefowl & 844 & 1 \\
\hline Phasianidae & Lophura & diardi & Siamese Fireback & 1,420 & 1 \\
\hline Phasianidae & Lophura & erythrophthalma & Crestless Fireback & 1,043 & 1 \\
\hline Phasianidae & Lophura & ignita & Crested Fireback & 2,175 & 1 \\
\hline Phasianidae & Lophura & inornata & Salvadori's Pheasant & $1,400^{*}$ & 1 \\
\hline Phasianidae & Lophura & leucomelanos & Kalij Pheasant & 995 & 1 \\
\hline Phasianidae & Lophura & nycthemera & Silver Pheasant & 1,750 & 1 \\
\hline Phasianidae & Pavo & muticus & Green Peafowl & 4,425 & 1 \\
\hline Phasianidae & Polyplectron & bicalcaratum & Grey Peacock-pheasant & 685 & 1 \\
\hline Phasianidae & Polyplectron & chalcurum & $\begin{array}{l}\text { Bronze-Tailed Peacock- } \\
\text { pheasant }\end{array}$ & 508 & 5 \\
\hline Phasianidae & Polyplectron & malacense & Malay Peacock-pheasant & 633 & 3 \\
\hline Phasianidae & Polyplectron & sumatrana & $\begin{array}{l}\text { Sumatran Peacock- } \\
\text { pheasant }\end{array}$ & 510 & 1 \\
\hline Phasianidae & Rollulus & rouloul & Crested Partridge & 232 & 1 \\
\hline Cariamidae & Cariama & cristata & Red-legged Seriama & 1,400 & 1 \\
\hline Cariamidae & Chunga & burmeisteiri & Black-legged Seriama & 1,298 & 1 \\
\hline Eurypygidae & Eurypyga & helias & Sunbittern & 222 & 1 \\
\hline Psophiidae & Psophia & leucoptera & Pale-winged Trumpeter & 990 & 1 \\
\hline Rallidae & Aramides & cajanea & Gray-necked Wood Rail & 397 & 1 \\
\hline Rallidae & Gallinula & chloropus & Moorhen & 340 & 2 \\
\hline Corvidae & Cissa & chinensis & Green Magpie & 132 & 1 \\
\hline Corvidae & Corvus & corone & Carrion Crow & 570 & 2 \\
\hline Corvidae & Garrulus & glandarius & Eurasian Jay & 161 & 1 \\
\hline Corvidae & Urocissa & erythrorhyncha & Blue Magpie & 214 & 1 \\
\hline Dicruridae & Dicrurus & annectans & Crow-billed Drongo & 44 & 1 \\
\hline Dicruridae & Dicrurus & macrocercus & Black Drongo & 50 & 1 \\
\hline Irenidae & Chloropsis & hardwickii & Orange-bellied Leafbird & 36 & 1 \\
\hline Muscicapidae & Copsychus & malabaricus & White-rumped Shama & 30 & 6 \\
\hline Muscicapidae & Enicurus & leschenaulti & White-crowned Forktail & 54 & 1 \\
\hline Muscicapidae & Enicurus & schistaceus & Slaty-backed Forktail & 31 & 1 \\
\hline Muscicapidae & Eupetes & macroceros & Malaysian Rail-babbler & ND & 6 \\
\hline Muscicapidae & Luscinia & cyane & Siberian Blue Robin & 15 & 6 \\
\hline Muscicapidae & Muscicapa & sp. & Flycatcher & 13 & 6 \\
\hline Muscicapidae & Myiophonus & caeruleus & Blue Whistling-thrush & 168 & 1 \\
\hline Muscicapidae & Pellorneum & capistratum & Black-capped Babbler & 21 & 6 \\
\hline Muscicapidae & Zoothera & dauma & Scaly Thrush & 104 & 1 \\
\hline Pittidae & Pitta & cyanea & Blue Pitta & 110 & 1 \\
\hline Pittidae & Pitta & granatina & Garnet Pitta & ND & 3 \\
\hline Pittidae & Pitta & guajana & Banded Pitta & 82 & 1 \\
\hline Pittidae & Pitta & oatesi & Rusty-naped Pitta & ND & 1 \\
\hline Pittidae & Pitta & caerulaea & Giant Pitta & ND & 4 \\
\hline Pittidae & Pitta & venusta & Graceful Pitta & ND & 4 \\
\hline Rhinocryptidae & Rhinocrypta & lanceolata & Crested Gallito & 64 & 1 \\
\hline Ramphastidae & Ramphastos & toco & Toco Toucan & 540 & 1 \\
\hline Rheidae & Rhea & americana & Greater Rhea & 23,000 & 1 \\
\hline Strigidae & Bubo & sumatranus & Barred Eagle Owl & $1,150^{*}$ & 3 \\
\hline Tinamidae & Crypturellus & $\mathrm{sp}$ & Tinamou & 390 & 1 \\
\hline
\end{tabular}

Sources: 1. Wildlife Conservation Society, unpublished survey data; 2. Heggelin et al. 2004; 3. Kawanishi 2002; 4. Martyr 1997; 5. Dinata et al. 2008; 6. Miura et al. 1997; 7. Jeganathan et al. 2002 
Camera traps are increasingly being used in avian ecology studies. A recent bibliography on the use of cameras in ecological research (A.F. O'Connell, unpublished data) between 1994 and 2005 lists 73 studies in which camera traps or remote video cameras were used to study avian ecology. The results indicate a growing interest in the use of remote cameras in ornithology: Between 1994 and 1999 the bibliography lists an average of 2.7 bird publications each year, whereas between 2000 and 2005 the average jumped to 11 publications per year. Most studies $(n=36)$ concerned nest predation and behavioural aspects of nesting ecology $(n=29)$. Bolton $e t$ al. (2007) provide an excellent overview the use of digital photography in studies of nest predation. Use of cameras at nest sites makes sense since cameras are very useful for collection of point source data. The remaining studies concerned use of cameras to monitor or census bird populations.

Picman and Schriml (1994) and Leimgruber et al. (1994) first documented patterns of bird nest predation on artificial nests of quail eggs using camera traps. The cameras were triggered by predators approaching the nest or moving the eggs, allowing researches to identify predators, determine the sequence of predator visitation, and determine the time of day of predation. Cameras have also been used to determine effects of habitat (Zegers et al. 2000, Thompson and Burhans 2003, Smith 2004) and nest type (Purcell and Verner 1999) on predation rates. In addition to camera traps, time lapse video cameras (Liebezeit and Luke 2003, Perkins et al. 2005) are often used in nest predation studies

Some of the more interesting uses of camera traps are to document behaviours at and away from nests. Video camera trapping proved pivotal in a recent debate over avian parental defence of nests (Bradley and Marzluff 2003, Pietz and Granfors 2005). Miura et al. (1997) used camera traps to identify frugivores (including birds) visiting over 70 species of trees in Malaysia, including Malaysian Rail-babbler Eupetes macrocerus. Kitamura et al. (2004) applied similar techniques to photograph frugivores and seed predators removing large-seeded Aglaia spectabilis fruits in Thailand, including the White-crested Laughingthrush Garrulax leucolophus. Cresswell et al. (2003) used cameras attached to model prey birds to assess whether Sparrowhawks Accipiter nisus prefer non-vigilant prey. Cameras were triggered by the vibration caused by the sparrowhawk striking the models of Red Junglefowl Gallus gallus and Greenfinches Carduelis chloris.

Camera traps have been used to document temporal activity budgets of forest mammals (Griffiths and van Schaik 1993, Laidlaw and Noordin 1998) as well as shifts in activity budgets in response to human disturbance in the forest (van Schaik and Griffiths 1996). We used camera traps in Bukit Barisan National Park Sumatra to document the activity of Great Argus Pheasants, illustrating their strict diurnal activity pattern (Figure 1 ). A careful analysis of body positions in photographs might provide more detailed insights into behavioural time budgets (foraging, moving feeding), although there have been no attempts to date.

Camera traps offer potential to monitor activities at points, including rates of visitations to nests, burrows or cavities, and feeding behaviour. They also can be used in conjunction with lures, baits, or decoys that incite a behaviour to record responses. If attractants are used to increase the rate of photograph acquisition, the researcher needs to pay attention to the storage capability of the camera (film or digital) and probably inspect the camera trap more frequently.

\section{New applications of camera trapping to forest birds}

In spite of the growing popularity of camera traps as a tool to study rare and elusive animals, there has been relatively little attention paid to the statistical analysis of camera trap studies, or to the use of camera in avian monitoring programmes. Although there has been rapid growth in our understanding of the role of detection probability $(p)$ in estimation of abundance and occupancy (Williams et al. 2002, Royle 2004, MacKenzie et al. 2006), practitioners have been slow to adopt methods that allow for statistically valid inferences based on different kinds of count data. 


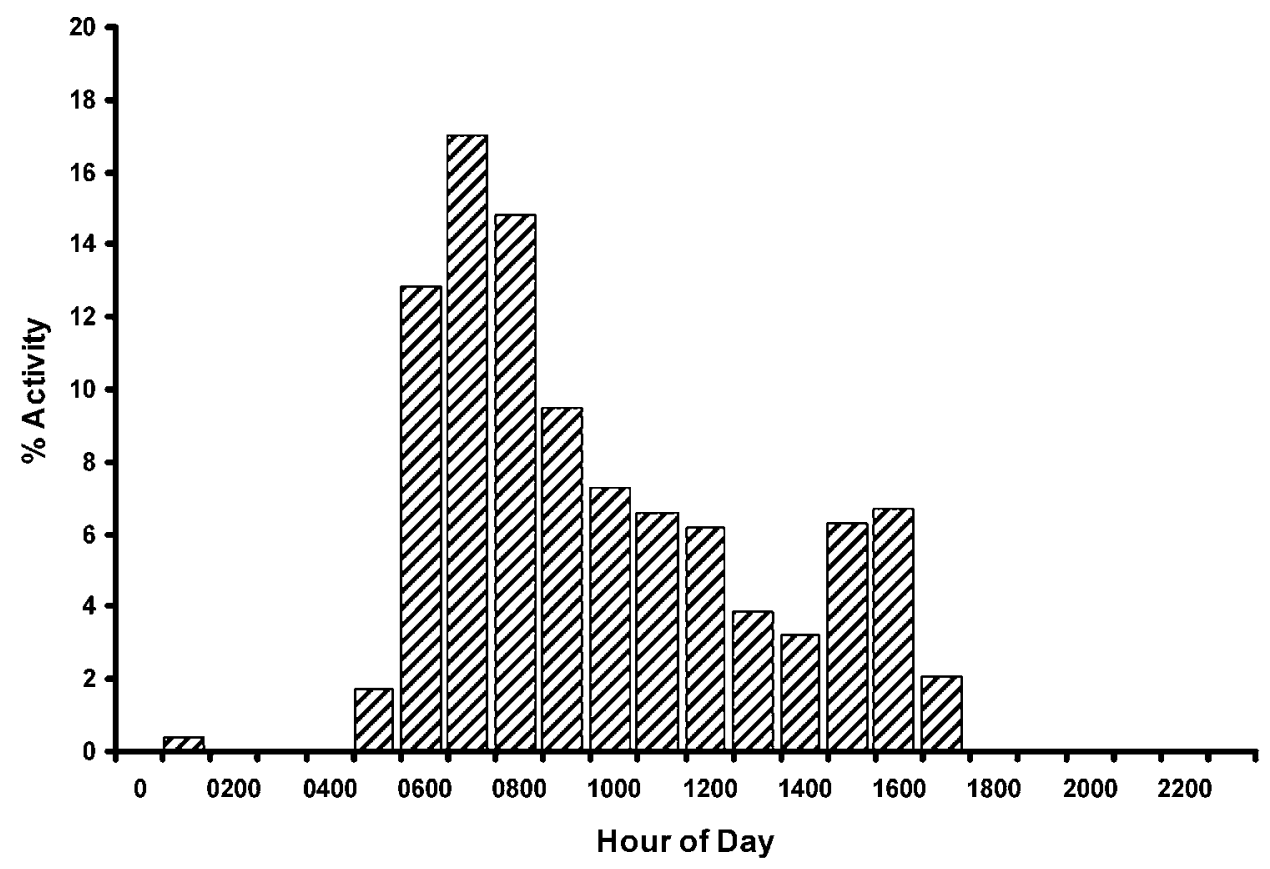

Figure 1. Hourly activity budget of Great Argus Pheasant determined from camera trap photographs ( $n=943$ photographs).

After species identification, the most fundamental information contained in camera trap data are the counts of photographs of a species. Count data however, are almost always an underestimate of abundance unless every animal is detected. If it is possible to mark a subpopulation of birds (C), using collars or patagial wing bands for example (Bartelt and Rusch 1980, Gaunt and Oring 1999), then camera traps can be used to estimate abundance $(N)$ using mark-resighting models (Bartmann et al. 1987, White 1993). In the simplest case, $C$ marked animals are released into the population and during a follow-up survey $n$ birds are counted including $c$ marked individuals. Detection probability $(\hat{p})$ is estimated by $c / C$ and the population is estimated by the application of a simple relationship

$$
\hat{\mathrm{N}}=\mathrm{n} / \hat{\mathrm{p}}
$$

Variance can be estimated using the delta method (Seber 1982). This can be easily expanded to multiple survey samples typical of camera trap surveys. Because $n$ photographs within a sampling period may include multiple counts of unmarked birds that moved past the camera more than once in a sample period, the multiple counts of identified birds can be used to adjust $n$ within a sampling period to yield $n^{*}$, the number of marked and unmarked animals in the sample. Abundance can then be estimated by $\mathrm{n}^{*} / \hat{\mathrm{p}}$ and variance estimated using the delta method. These methods should produce unbiased estimates for species that are not highly clumped in space. Precision of estimates will be affected by the true abundance, the number of marked animals in the population and the encounter rate for marked animals. To date, these methods have not been attempted using camera traps.

Counts adjusted for sampling effort are referred to as trapping rates and are often used for abundance indices when it is not possible to recognize individual animals under the assumption that, all things being equal, trapping rates should be higher in areas with larger numbers of 
individuals. Supporting this idea, we often find that trapping rates correlate significantly with abundance or density estimates ( $\mathrm{O}^{\prime}$ Brien et al. 2003, Silveira et al. 2003, O'Brien unpubl. data). Use of counts or trapping rates, however, almost always results in bias because these indices do not control for the probability of detection, and changes in the index cannot be attributed unambiguously to changes in abundance versus changes in detection. Also, trapping rate indices need to be calibrated for each species, for each time, and for each site where they are used, making rigorous application of trapping rates impractical to apply ( $\mathrm{O}^{\prime}$ Brien in press).

A potentially useful application of trapping rate indices for cameras is outlined by Rowcliffe et al. (2008). They developed a generalized version of a model used by Stephens et al. (2006) for estimating density from track counts. The Rowcliffe model attempts to simulate the process underlying a photographic capture by assuming that for a randomly moving animal, encountering a randomly placed camera, the number of photographs obtained is a positive function of the density of the animals, their speed of movement, the maximum detection distance at which a camera is triggered, the arc of detection in which the camera is triggered and the length of time over which the camera is set. In addition, for animals that habitually travel in groups, the independent unit photographed is the group, and assuming one photograph per group contact, the number of photographs should therefore decrease with group size. Given speed, distance of detection and group size, the trapping rate can be converted to density by a simple correction factor. They considered power and bias in relation to sampling effort and recommend that at least 20 cameras be deployed until at least 1o photographs are obtained, usually less than 1,00o trap-days. Although Rowcliffe et al. (2008) have demonstrated the potential of this method for mammals, it has not been tested on birds.

Most studies of avian distribution and many studies of habitat preference rely on occurrence records or presence/absence data. Presence/absence data results in a count of occupied sites and is subject to the same problems as counts of birds. Estimates of site occupation are biased because the assumption that all animals are detected when they are present $(\hat{p}=1)$ is rarely true. Occupancy analysis (MacKenzie et al. 2002, 2006) is an estimation method that generalizes presence-absence data to detection-nondetection data with three possible outcomes: present and detected, present but not detected, and not present. This approach allows the estimation of the proportion of sampling units that are occupied $(\psi)$ when detection is imperfect (detection probability, $\hat{p}<1$ ). Occupancy analysis uses replicated visits to sampling units in which a bird species is recorded as present ( $I$ ) if detected and not detected (O) if they are not found during a search. The histories of detections at sample sites are treated like a capture history in a capturerecapture analysis except that sites where a species is never encountered are included. MacKenzie et al. (2002) present maximum likelihood methods that allow direct and unbiased estimates of the proportion of occupied sites (equal to the probability that a site is occupied) and the detection probability. The method allows explicit incorporation of covariates that might affect either the probability of occupancy or the detection probability. The method also allows for multi-season modeling that incorporates local extinction and colonization (MacKenzie et al. 2003) and has been applied to estimation of extinction and colonization rates of Grey Heron Ardea cinerea and Purple Heron A. purpurea colonies when not all colonies are detected (Barbraud et al. 2003). Occupancy monitoring has been proposed as an alternative to monitoring abundance in large scale monitoring programmes (MacKenzie et al. 2002) where occupancy may serve as a surrogate for abundance (MacKenzie and Nichols 2004).

An acknowledged limitation of occupancy surveys is the inability to generate information about abundance. This led to a second advance: the use of count data to estimate abundance when animals are not marked or individually recognizable. Royle and Nichols (2003) and Royle (2004) developed methods for incorporating variation in detectability due to differences in animal abundance and then using this heterogeneity in detection to make inferences about abundance in an occupancy analysis framework. The methods rely on replicated visits to sites where counts of a species are recorded and finite mixture models of detection probability are used to generate mixing distributions that are estimates of the distribution of animal abundance among sites 
(Royle and Nichols 2003). Point abundance estimates can be regarded as the number of birds that are potentially detectable at a point, such as a point on a breeding bird survey or a camera trap location. The distribution represents point estimates of abundance that may be quite small, but the average number of individuals observed at each site may be a very good estimate. When sample sites are discrete, or when the effective sampling area is known, an estimate of total abundance may be obtained from area expansion of the average point abundance. When the effective sample area is less clear, the average point estimate may still be used as a bias-corrected monitoring metric that tracks changes in abundance rather than detection probability (Royle 2004). As with occupancy analysis, factors that lead to spatial or temporal variation in abundance may be modeled directly as covariates. This is important to the development of models of how avian abundance may change in response to habitat or anthropogenic changes across a landscape.

The methods of Royle and Nichols (2003) and Royle (2004) have been applied to avian point count surveys (Breeding Bird Surveys [Robbins et al. 1986]) where it is often difficult to identify the number of unique individuals observed. A parallel situation arises in camera trap studies, which can be regarded as point count sampling of terrestrial species. In both cases, recognition of individuals is difficult, data often are sparse, containing low counts and many zero counts. Bias in occupancy and point abundance estimates typically occurs for species with very low detection probabilities $(\leqslant$ o.I) and when few sites are sampled. Simulations by Royle and Nichols (2003) indicate that for a detection probability of 0.1, IOO camera trap points sampled on 10 occasions may yield practical estimates of point abundance. For detection probabilities $\geqslant 0.3$, five replications may be adequate. Fortunately, temporal replication is easy in camera trap surveys, and sampling $8 \mathrm{o}$ or more points is becoming common practice in camera trap surveys.

\section{An example using Great Argus Pheasants}

Between 1998 and 2006, we conducted a series of studies of Great Argus Pheasants in the Bukit Barisan Selatan National Park as part of a large scale forest and wildlife monitoring programme. The studies included a radio telemetry study of movements and habitat preference (Winarni 2002, Winarni et al. unpubl. data), a survey of pheasants in forest fragments of southern Sumatra (Winarni et al. 2005), and an intensive camera trap survey of a $6 \mathrm{~km}^{2}$ portion of the Way Canguk Research area in BBSNP on five occasions between September 1998 and November 2001 (O'Brien et al. 2003, Winarni et al. unpubl. data, Thompson et al. in prep.). Finally, a parkwide camera trap monitoring programme was initiated in 1998 to monitor Sumatran Tigers (Panthera tigris sumatrae) and their prey, including Great Argus Pheasants. Between 1998 and 2006 five surveys were conducted in 10 sampling blocks ( $20 \mathrm{~km}^{2} / \mathrm{block}$ ) located systematically throughout the park (see O'Brien et al. 2003 for sampling design).

Winarni (2002) used radio telemetry to establish that male Great Argus Pheasants were highly territorial, forest specialists, preferring undisturbed forest with large trees for foraging and location of dancing grounds. This preferred forest type comprises approximately $40 \%$ of the Way Canguk Research area. Winarni et al. (2005) found that Great Argus Pheasants preferred large, intact blocks of forest as well, and were rarely found in lowland forest blocks $<50 \mathrm{~km}^{2}$ in area.

\section{Occupancy, habitat preference, and correlates of distribution}

Between 1998 and 2001, we deployed 38 cameras in the Way Canguk Study Area for an average of 28 days/camera/replication. Once films were retrieved and processed, we scored Great Argus Pheasant photographs as independent events following the methods of $\mathrm{O}^{\prime} \mathrm{Brien}$ et al. (2003), resulting in 20-84 pheasant observations per sampling occasion. Observed or naïve estimates of occupancy, ranged from $23.8 \%$ to $37.5 \%$ of the study area (Figure 2). Because we were interested in a relatively small area, equal to approximately 90 male pheasant territories, we conducted a single season occupancy analysis (MacKenzie et al. 2002) for each of the five replications, assuming a constant proportion of occupancy, $\psi$, and constant detection probability, 


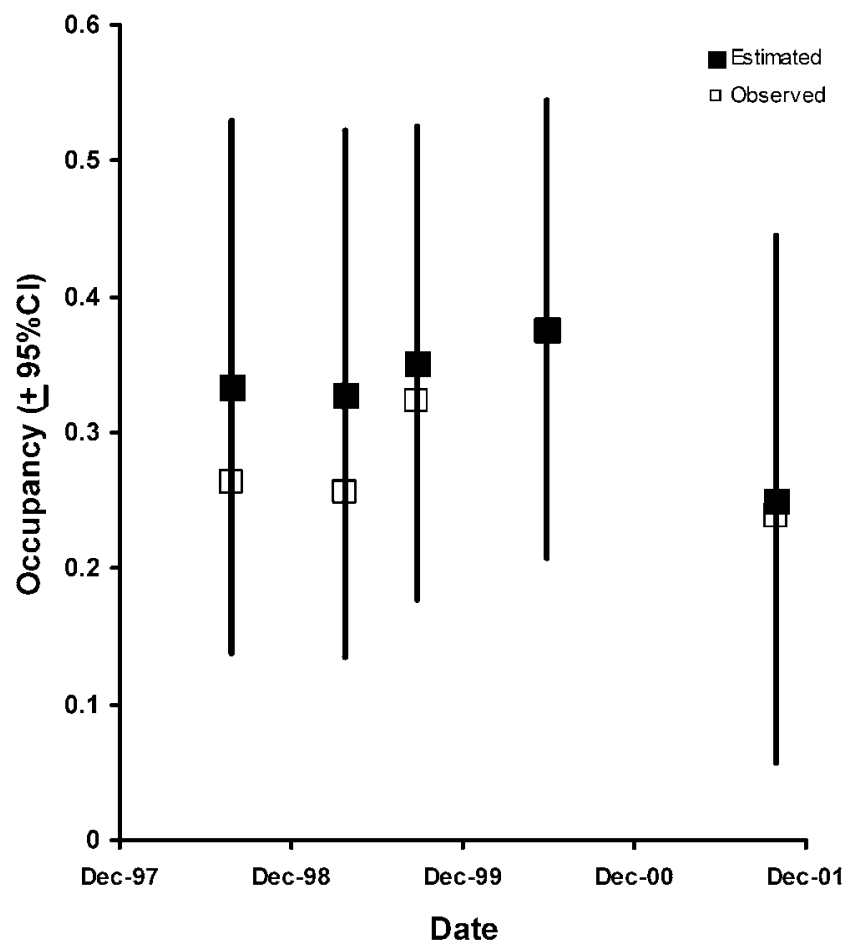

Figure 2. Observed and estimated average habitat occupancy (with $95 \%$ confidence intervals) by Great Argus Pheasants in Way Canguk Research Area between 1999 and 2001.

p [model $\psi() p.($.$) ], for each analysis, rather than using a multi-season modeling strategy.$ Estimated habitat occupancy $(\hat{\psi})$ ranged from $25.1 \%$ to $37.6 \%$ of the study area, $0.1 \%-7.2 \%$ higher than naïve estimates. A primary advantage of occupancy analysis is that it provides an estimate of variance in occupancy so we can evaluate the precision of the estimates and the significance of changing values of $\hat{\psi}$. Precision is relatively poor for this example (wide confidence intervals) due to the small number of traps deployed and detection probabilities $<$ o.I in most of the trials. Over the five replications, $\hat{\psi}$ did not change significantly and did not exceed the estimate of percent of preferred habitat in the study area. Great Argus Pheasant were only photographed once at a site that was not imbedded or immediately adjacent to preferred habitat (Winarni et al. unpubl. data). During this same time, line transect density estimates of calling males and of all pheasants observed indicate that the Great Argus Pheasant population tripled in density ( $\mathrm{O}^{\prime}$ Brien and Kinnaird unpublished data, Thompson et al. in prep.), probably representing recovery from the severe 1997-98 ENSO drought. Thus, in spite of rapid population growth, the pheasants retained their preference for tall, primary forest and did not expand into less-preferred habitat.

Because BBSNP is under pressure from threats of deforestation (Kinnaird et al. 2003, Gaveau et al. 2007) and hunting (O'Brien et al. 2003, Wibisono 2006), we next asked what proportion of the park was occupied by Great Argus Pheasant at the start of our study, and how occupancy might be affected by proximity to the park edge (in $\mathrm{km}$ ), villages (in $\mathrm{km}$ ) and human population pressure (high density versus low density; O'Brien et al. 2003). We also included elevation (in $\mathrm{m}$ ) in the analysis because the species is described as a lowland specialist (Madge and McGowan 2002) on Sumatra with a maximum elevation distribution of $500 \mathrm{~m}$. We therefore expected that elevation would affect Great Argus distribution independent of the effect of human pressure. 
We used GIS to map the positions of 215 camera traps relative to the park boundary, nearest village and elevation, and classified each camera according to the human density adjacent to the park boundary. An examination of independent photographs at locations distributed from sea level to 1,300 m indicated that Great Argus Pheasant occurred more often at lower elevations: no Great Argus Pheasant were photographed at elevations $>1,000 \mathrm{~m}$. A Chi-square analysis of the frequency of photographs by $100 \mathrm{~m}$ elevation classes suggests that Great Argus Pheasants are photographed much less than expected above $700 \mathrm{~m}\left(\chi^{2}{ }_{7}=32.8, P<0.0001\right.$, after collapsing cells $700 \mathrm{~m}$ and above due to o observations).

We then conducted an occupancy analysis with covariates to assess the effect of proximity to human villages, human density, park boundary and elevation. We used a multi-model selection process (Burnham and Anderson 2002) to compare the relative merits of a number of possible models explaining variation in occupancy and detection probability. Occupancy and detection were first modeled as constant across sites and samples [model $\psi() p.()$.$] . We then modeled$ occupancy as a function of combinations of the four covariates and detection probability as a function of human density on the boundary, distance to village, and distance to park boundary. Preliminary screening indicated that none of the models incorporating covariates into the detection probability were supported, and we evaluated 25 models that we considered to be most reasonable. We used AIC criteria to select the most appropriate model for the data, striking a balance between an adequate description of variation in the data while minimizing the number of parameters in the model (Burnham and Anderson 2002). We used the difference between a model's AIC and the low-AIC model ( $\triangle$ AIC) to calculate model likelihoods and model weights. Model likelihoods indicate the strength of evidence supporting a particular model. Model weights reflect the evidence that a model is 'the best model' for the data, among the models being considered in the analysis. Sometimes, the weight of evidence may support several alternative models, indicating that the 'best' model might vary from data set to data set. In this case, multimodel inference based on model averaging may improve the stability the parameter estimates (Burnham and Anderson 2002). Model averaging uses AIC weights to develop weighted parameter estimates and obtain a final model.

Considering only the models with model likelihoods $>$ o resulted in the selection of 12 possible models (Table 2) ranked by AIC. Occupancy estimates ranged from $27.95 \%$ for the most likely model to $31.73 \%$ for the least likely model. Covariate coefficients for models that included human density adjacent to the park and distance to park edge all included o in the $95 \%$ confidence interval. Only the coefficient for elevation was consistently different from o in the models considered. The most likely model included occupancy as a function of distance to park boundary and elevation and a constant detection probability $[\psi($ edge,elev. $) p()$.$] . There was$ almost equivalent support for a second model that added distance to village as a covariate of occupancy $[\psi($ edge, elev., village $) p()$.$] . Detection probabilities were relatively constant across$ models, ranging from 0.073 to 0.076 .

We can see from the distribution of AIC weights (Table 2) that there is not strong support for the low-AIC, best model. We would expect variation in the choice of best model if we could draw multiple independent samples from the same population. In this situation, model uncertainty is high since there are reasonable competing models for the same data. We used model averaging to develop weighted estimates of occupancy and detection. The model averaged estimate of occupancy was $0.2808(\mathrm{SE}=0.09)$ with a detection probability of $0.0752(\mathrm{SE}=0.0077)$. Across models, elevation ranks as the most important variable based on the sum of AIC weights for models including each covariate (Burnham and Anderson 2002). A plot of the model averaged probability of occupancy for each camera trap point as a function of elevation (Figure 3 a) results in a very good fit $\left(r^{2}=0.82\right)$ compared to the second most important covariate, distance to park boundary (Figure $3 \mathrm{~b} ; r^{2}=0.02$ ). The likelihood of occupancy below $600 \mathrm{~m}$ is 0.465 whereas the likelihood above $600 \mathrm{~m}$ is only 0.271 . By comparison, the likelihood of occupancy within $2 \mathrm{~km}$ of the park boundary is 0.465 , and differs little from the likelihood of occupancy for camera trap points greater than $2 \mathrm{~km}$ from the boundary (0.536). We conclude that habitat occupancy by 


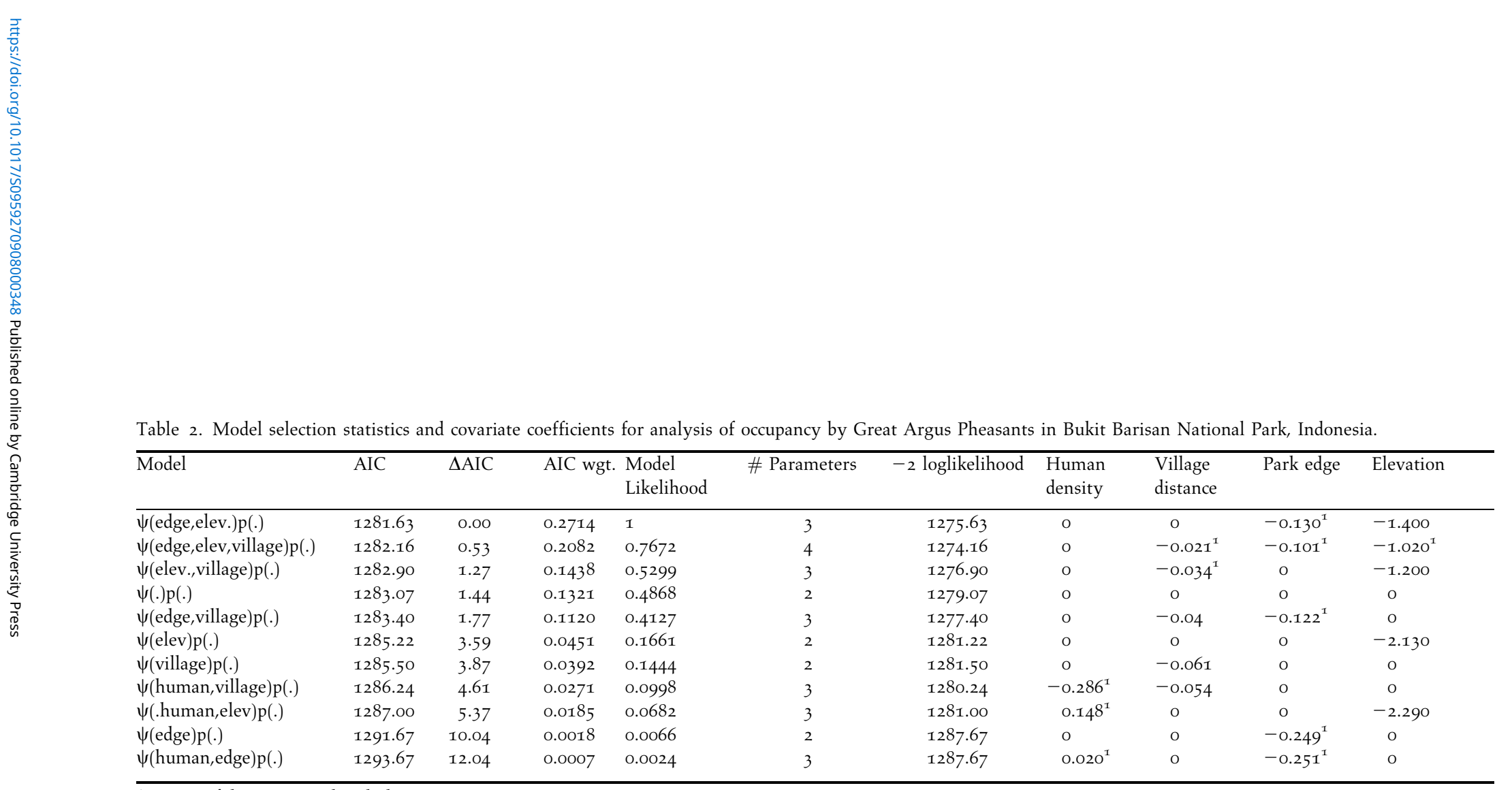

${ }_{95}^{1} \%$ confidence interval includes $\mathrm{O}$. 
(a)

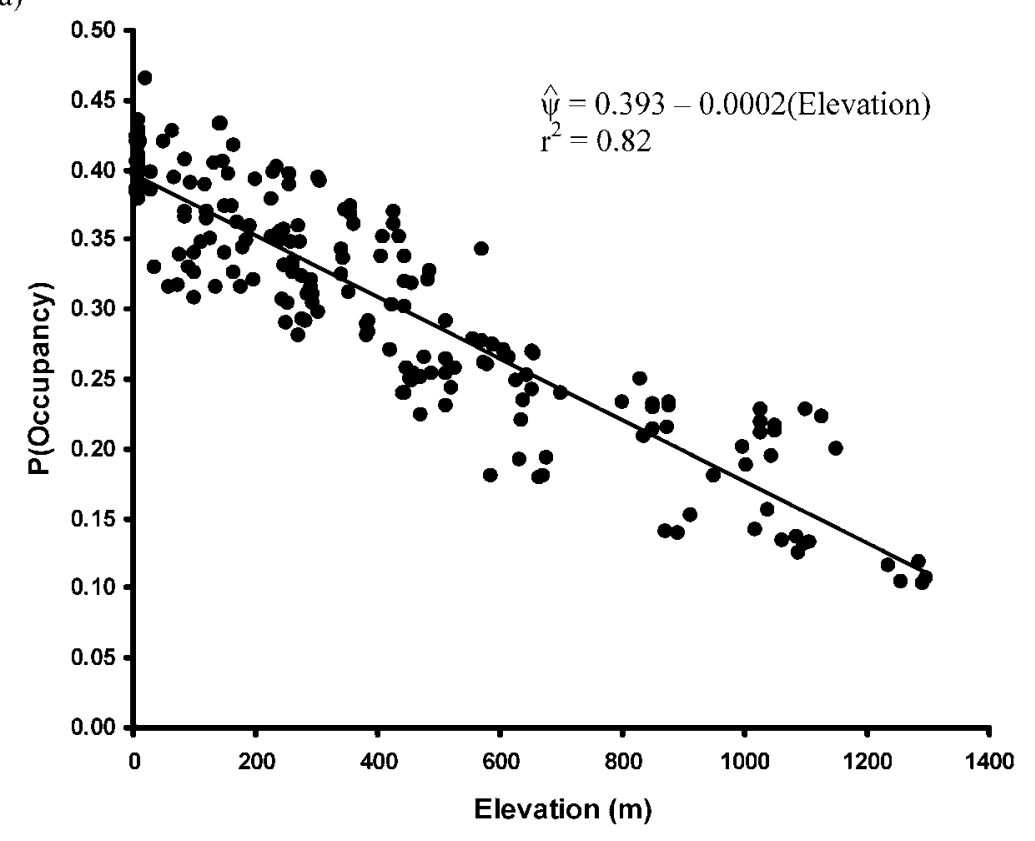

(b)

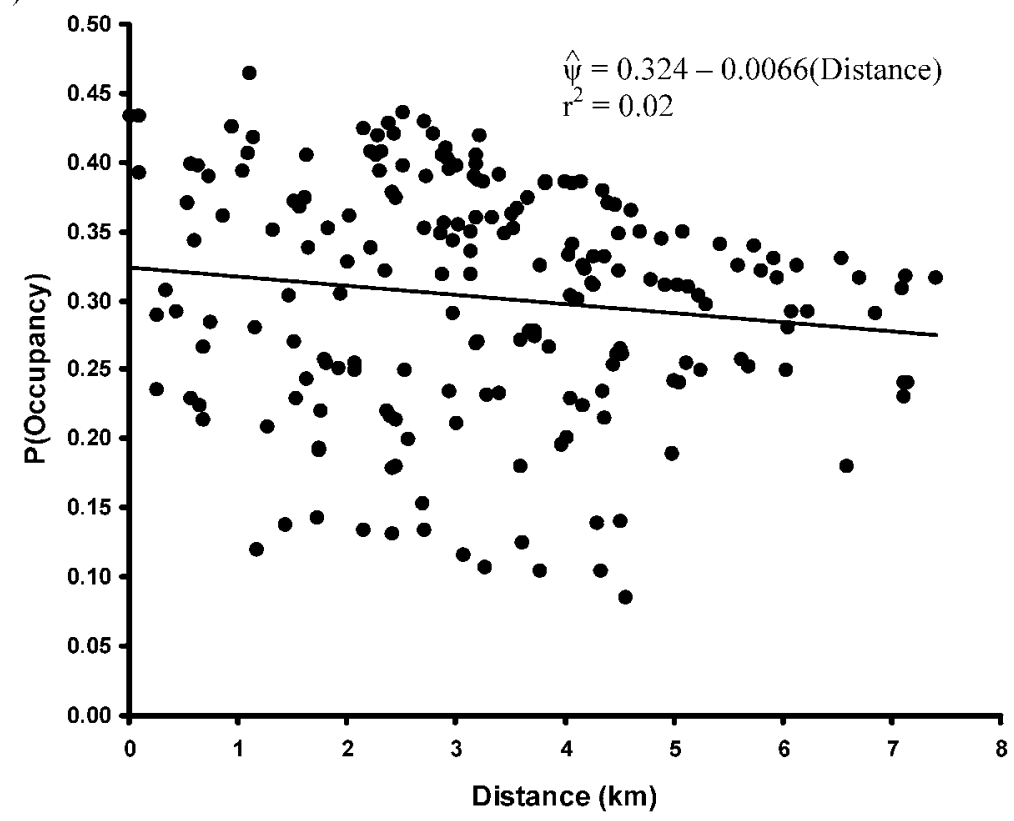

Figure 3. Model averaged probabilities of occupancy as a function of (a) elevation and (b) distance to park boundary. 
Great Argus Pheasant in BBSNP declines as elevation increases and is relatively insensitive to effects of human density, proximity to borders or villages.

\section{Trends in occupancy and abundance}

Finally, we wished to assess the trends in the abundance and distribution of Great Argus Pheasants in BBSNP between 1998 and 2006. During this time, the park experienced ongoing deforestation with estimates of deforestation rates varying from $0.64 \% \mathrm{yr}^{-1}$ (Gaveau et al. 2007) to $2 \% \mathrm{yr}^{-1}$ (Kinnaird et al. 2003). At the same time, the park was subject to three ENSO droughts, which may have affected survival of pheasants. We again used single-season models to estimate occupancy by considering three models: the constant occupancy and detection probability model [model $\psi() p.()$.$] , the Royle-Nichols abundance induced heterogeneity model$ (Royle and Nichols 2003) and the Royle replicated count data model (Royle 2004). The RoyleNichols model and the Royle model each provide estimates of average point abundance. Other possible models to consider might include addition of covariates (i.e. sampling blocks or elevation), or multi-season models to directly estimate extinction and colonization parameters.

Between 1998 and 2006 we conducted five replicated surveys in the park using the sampling design described in O'Brien et al. (2003). Across the five surveys, $15 \%$ of cameras malfunctioned, were destroyed by Asian Elephants Elephas maximus or were taken by humans, and loss rate increased over time as cameras wore out. Cameras were operational for up to 40 days but we truncated the data at 30 days, when $89 \%$ of the cameras retained unused frames of film. The data sets therefore contained some missing values for $11 \%$ of cameras.

Occupancy estimates were $9 \%$ to $27 \%$ higher than naïve estimates (Figure $4 \mathrm{a}$ ) although the two estimates were not significantly different. Both naïve and estimated occupancy decline over time in the park. Naive occupancy rose initially and then declined after the 2000 survey. Estimated occupancy also rose initially but declined more consistently than the naïve occupancy. Despite low detection probabilities (0.04-0.08), precision was much better in the park survey than in the Way Canguk example (Figure 2: Way Canguk CV: $22-39 \% /$ survey; Park CV: $12-$ $24 \% /$ survey) due to much higher sampling effort. Declines in observed occupancy were highest in the middle and northern sample blocks (Block 4-10), averaging $64 \%$. In the south, observed occupancy increased by $12 \%$ between 1998 and 2005. We did not find strong support for heterogeneity in occupancy estimates due to effects of point abundance in any of the surveys (Table 3). Model $\psi() p.($.$) was considered the best model in all surveys, followed by the Royle-$ Nichols model. Royle-Nichols model seemed to perform considerably better than the Royle model based on smaller $\triangle \mathrm{AIC}$, though neither abundance-based model was supported for any survey. Estimated occupancy based on the model $\psi() p.($.$) range from 37 \%$ in 2000 to $13.3 \%$ in 2005. The 2000 estimate is significantly higher than the 2005 estimate and the confidence interval of the 1998 estimate overlaps only slightly with the confidence interval of 2005 estimate, suggesting an important decline in area occupied by pheasant between 2000 and 2005 .

Royle-Nichols point abundance estimates $(\hat{\lambda})$ display a declining pattern similar to occupancy (Figure $4 \mathrm{~b})$ : the average point abundance estimate for $2000(\hat{\lambda}=1.04)$ is significantly greater than all other estimates. The other $\hat{\lambda}$ estimates range from 0.23 to 0.44 and, although they tend to decline over time, the point estimates are not significantly different. Point abundance estimates from the Royle models are similar to the Royle-Nichols estimates and indicate the same trend over time.

We conclude from this analysis that the area occupied by Great Argus Pheasants in BBSNP is declining at a rate of approximately $6-8 \%$ year $^{-1}$. The pattern of change in observed occupancy (strong decline in north, increase in the south) is consistent with the pattern of deforestation in BBSNP (Kinnaird et al. 2003). The trend in average point abundance also declines over time (4$6 \% /$ year). The apparent outlier of point abundance in 2000 is corroborated by line transect data 
(a)

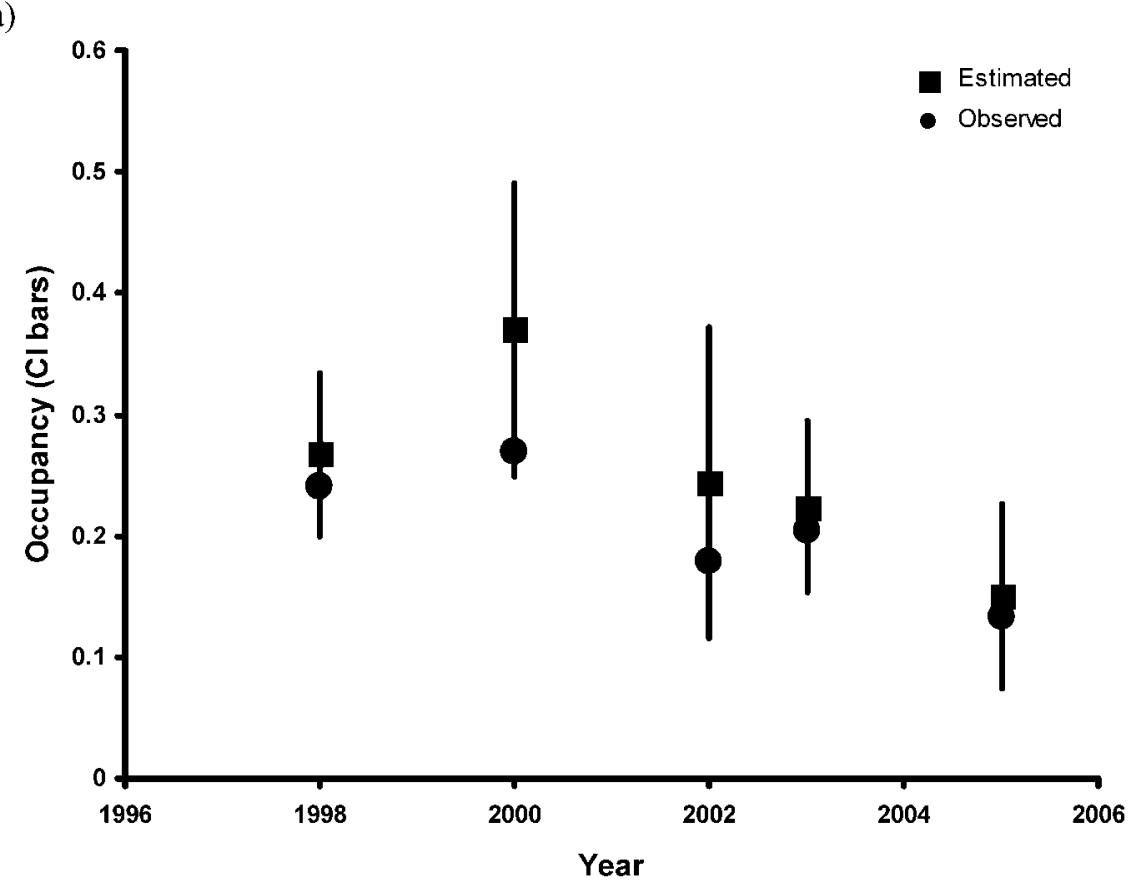

(b)

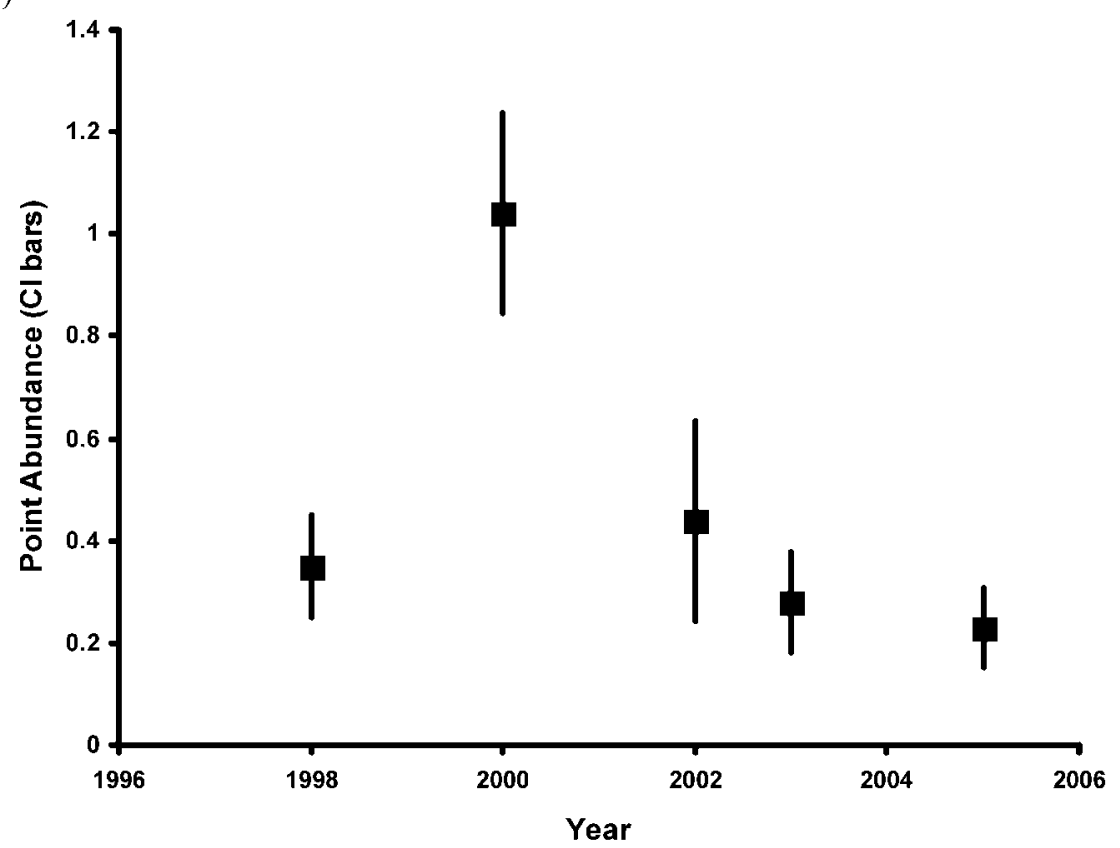

Figure 4. Estimates of (a) occupancy and (b) average point abundance (with $95 \%$ confidence interval) of Great Argus Pheasant in BBSNP between 1998 and 2006. 
Table 3. Model selection statistics for analysis of occupancy over five surveys of Great Argus Pheasants in BBSNP, Indonesia.

\begin{tabular}{|c|c|c|c|c|c|c|}
\hline Year and Models & AIC & $\Delta \mathrm{AIC}$ & $\begin{array}{l}\text { AIC } \\
\text { wgt }\end{array}$ & $\begin{array}{l}\text { Model } \\
\text { Likelihood }\end{array}$ & \# Parameters. & -2 Loglikelihood \\
\hline \multicolumn{7}{|l|}{1998} \\
\hline$\psi(.) \mathrm{p}()$. & 1137.41 & 0.00 & 1 & 1 & 2 & 1133.41 \\
\hline Royle-Nichols model & $1194 \cdot 33$ & 56.92 & $\mathrm{O}$ & $\mathrm{O}$ & 2 & 1190.33 \\
\hline Royle model & 1562.07 & 424.66 & $\mathrm{O}$ & $\mathrm{O}$ & 2 & 1558.07 \\
\hline \multicolumn{7}{|l|}{2000} \\
\hline$\psi(.) \mathrm{p}()$. & 848.16 & 0.00 & 1 & 1 & 2 & 844.16 \\
\hline Royle-Nichols model & $1059 \cdot 33$ & 211.17 & $\mathrm{o}$ & $\mathrm{o}$ & 2 & $1055 \cdot 33$ \\
\hline Royle model & 2940.86 & 2092.70 & o & $\mathrm{o}$ & 2 & 2936.86 \\
\hline \multicolumn{7}{|l|}{2002} \\
\hline$\psi(.) \mathrm{p}()$. & 550.73 & 0.00 & 1 & 1 & 2 & 546.73 \\
\hline Royle-Nichols model & 711.81 & 161.08 & $\mathrm{O}$ & $\mathrm{O}$ & 2 & 707.81 \\
\hline Royle model & 713.78 & 163.05 & o & o & 2 & 709.78 \\
\hline \multicolumn{7}{|l|}{2003} \\
\hline$\psi(.) \mathrm{p}()$. & 702.86 & 0.00 & 1 & 1 & 2 & 698.86 \\
\hline Royle-Nichols model & 776.19 & $73 \cdot 33$ & $\mathrm{o}$ & o & 2 & 772.19 \\
\hline Royle model & 1008.70 & 305.84 & $\mathrm{O}$ & $\mathrm{O}$ & 2 & 1004.70 \\
\hline \multicolumn{7}{|l|}{2005} \\
\hline$\psi(.) \mathrm{p}()$. & $405 \cdot 54$ & 0.00 & 1 & 1 & 2 & 401.54 \\
\hline Royle-Nichols model & 609.74 & 204.20 & $\mathrm{o}$ & $\mathrm{O}$ & 2 & $605 \cdot 74$ \\
\hline Royle model & 738.49 & 332.95 & $\mathrm{O}$ & $\mathrm{o}$ & 2 & 734.49 \\
\hline
\end{tabular}

in Way Canguk. Between 1998 and 2001, the Great Argus Pheasant population in Way Canguk and in the park tripled (Winarni et al. unpubl. data). It appears that after this increase the park population declined again to a level below 1998. Although these trends are not statistically significant $(P>0.05)$, the consistent decline since 2000, in both occupancy and abundance, is cause for concern.

We have chosen to focus on the use of camera traps to estimate state variables, abundance and occupancy, that are important to many topics in ecology and conservation. Extension of these techniques to open populations using multi-season models (Williams et al. 2002, MacKenzie et al. 2006) will allow estimation of vital rates such as survival, emigration, extinction and colonization. These techniques rely on incorporating detection probabilities to correct for bias and produce accurate estimators with estimates of precision. Like any estimator, however, accuracy depends on meeting the underlying assumptions of the model. Violation of assumptions may result in biased estimates. Precision will be a function of rarity, detection probability and sampling effort. Precision improves as detection probability increases for a given level of effort. For example, for a bird with a detection probability of 0.04 and true occupancy of $60 \%$ of survey sites (widespread but hard to detect), a survey of 100 camera sites and 30 days of sampling should yield an expected estimate with $1 \%$ positive bias and a CV of $15 \%$, whereas a similar survey for a bird with detection probability of 0.08 results in no bias and a CV of $9 \%$. As a species becomes rarer, spatially clumped or more difficult to detect, accuracy and precision will decline, but this is a general problem of sampling rare populations.

For a given detection probability, precision improves with number of sites sampled and with number of replications per site. Most of the methods discussed recommend increasing the number of sampling occasions to improve precision, but caution that too many sampling occasions may result in violation of closure assumptions. Occupancy and point abundance methods recommend at least three sampling occasions and most modeling results indicate a 
minimum of five occasions. Fortunately, camera trap surveys typically operate over weeks and a sampling occasion can be defined by the investigator based on knowledge of the species or by the photographic trapping rates.

The question of whether camera trap techniques can be applied to groups of non-terrestrial birds remains unanswered but intriguing. To date, photographic records of non-terrestrial birds captured during terrestrial mammal surveys have been opportunistic. Many sampling techniques such as rodent trapping (Malcolm 1991, Lambert et al. 2005) that were developed for use on the ground have been successfully employed in the trees. Kierulff et al. (2004) have used camera traps mounted on trees to photograph rare primates visiting a baited platform. Whether such a technique might work for rare birds in the canopy would require a careful consideration of other, more traditional sampling techniques.

Colin Bibby was a great advocate of rigorous, quantitative bird surveying methods (Bibby et al. 2000a) and fieldcraft (Bibby et al. 200ob). Clearly, camera traps offer great potential for improving our understanding of terrestrial forest birds and moving research on rare and cryptic birds from presence/absence and relative abundance surveys to more substantive population dynamics and statistically sound monitoring. That camera trapping has been under-utilized in bird studies is an understatement: bird photographs are often considered by-catch in mammaloriented camera trap studies and filed, rather than analyzed. Camera trapping is revolutionizing the study of elusive mammals, and we believe that there is a bright future for elusive birds as well.

\section{Acknowledgements}

Our research was a collaborative effort by the Wildlife Conservation Society and the Indonesian Ministry of Forestry's Department for Protection and Conservation of Nature. The research was funded by the Wildlife Conservation Society, Edith McBean, the Save the Tiger Fund, a special project of the National Fish and Wildlife Foundation in partnership with the Exxon Mobil Corporation, the U.S. Fish and Wildlife Service Rhinoceros and Tiger Conservation Fund. Bird observations from WCS camera trap surveys were provided by M. Gumal, A. Johnson, A. Lynam, A. Noss, R. Wallace, J. Walston and H. Wibisono. We would like to thank J. Robinson, J. Ginsberg, M. Rao, F. Bagley, J. Seidensticker and D. Phemister for their support and advice during this project. We especially thank H. Wibisono, U. Wijayanto, I. Tanjung, Sunarto, M. Iqbal, N. Winarni and A. Dwiyahreni for assistance in data collection, E. Sanderson and K. Fisher for assistance in GIS analysis, J. Thompson for his input on point abundance estimates, and C. Sheppard for providing bird weights. We thank two anonymous reviewers for their very constructive comments.

\section{References}

Barbraud, C., Nichols, J. D., Hines, J. E. and Hafner, H. (2003) Estimating rates of local extinction and colonization in colonial species and an extension to the metapopulation and community levels. Oikos 101: 113-126.

Bartelt, G. A. and Rusch, D. H. (1980) Comparison of neck bands ad patagial tags for marking American coots. J. Wildl. Manage. 44: 236-241.

Bartmann, R. M., White, G. C., Carpenter, L. H. and Garrott, R. A. (1987) Aerial mark-recapture estimates of confined mule deer in pinyon-juniper woodland. J. Wildl. Manage. 51: 41-46.

Beck, H. and Terborgh, J. (2002) Groves versus isolates: How spatial aggregation of Astrocaryum murmuru palms affects seed removal. J. Trop. Ecol. 18: 275-288.

Bibby, C. J., Burgess, N. D., Hill, D. A. and Mustoe, S. (2000a) Bird census techniques. $2^{\text {nd }}$ Edition. San Diego: Academic Press.

Bibby, C. J., Jones, M. and Marsden, S. (20oob) Expedition field techniques: Bird 
surveys. London: Royal Geographical Society.

Bolton, M., Butcher, N., Sharpe, F., Stevens, D. and Fisher, G. (2007) Remote monitoring of nests using digital camera technology. J. Field Ornithol. 78: 213-220.

Bradley, J. E. and Marzluff, J. M. (2003) Rodents as nest predators: Influences on predatory behavior and consequences to nesting birds. Auk 120: 1180-1187.

Buckland, S. T., Summers, R. W., Borchers, D. L. and Thomas, L. (2006) Point transect sampling with traps or lures. J. Appl. Ecol. 43: 377-384.

Burnham, K. P. and Anderson, D. R. (2002) Model selection and multimodel inference: A practical information-theoretic approach. $2^{\text {nd }}$ edition. New York: Springer-Verlag.

Cresswell, W., Lind, J., Kaby, U., Quinn, J. L. and Jokobsson, S. (2003) Does an opportunistic predator preferentially attack nonvigilant prey? Anim. Behav. 66: 643-648.

DeLuca, D. W. and Mpunga, N. E. (2002) Preliminary observations of Lowe's Servaline Genet (Genetta servalina lowei) from Udzungwa Mountains National Park, Tanzania. Small Carnivivore Conserv. 27: 17-28.

Dinata, Y., Nugroho, A., Achmad Haidir, I. and Linkie, M. (2008) Camera trapping rare and threatened avifauna in westcentral Sumatra. Bird Conserv. Internatn. 18: $30-37$.

Gaunt, A. S. and Oring, L. W. (1999) Guidelines to the use of wild birds in research. Washington DC: Ornithological Council.

Gaveau, D. L. A., Wandono, H. and Setiabudi, F. (2007) Three decades of deforestation in southwest Sumatra: Have protected area halted forest loss and logging, and promoted re-growth? Biol. Conserv. 134: 495-504.

Griffiths, M. and van Schaik, C. (1993) The impact of human traffic on the abundance and activity periods of Sumatran rainforest wildlife. Conserv. Biol. 7: 623-626.

Heggelin, D., Bontadina, F., Gloor, S., Swild, J. R., Müller, U., Breitenmoser, U. and Deplazes, P. (2004) Baiting red foxes in an urban area: A camera trap study. J. Wildl. Manage. 68: 1010-1017.
Jeganathan, P., Green, R. E., Bowden, C. G. R., Pain, D. and Rahmani, A. (2002) Use of tracking strips and automatic cameras for detecting critically endangered Jerdon's coursers Rhinoptilus bitorquatus in scrub jungle in Andhra Pradesh, India. Oryx 36: 182-188.

Karanth, K. U. (1995) Estimating tiger Panthera tigris populations from camera trap data using capture-recapture models. Biol. Conserv. 71: 333-338.

Karanth, K. U. and Nichols, J. D. (1998) Estimation of tiger densities in India using photographic captures and recaptures. Ecology 79: 2852-2862.

Karanth, K. U., Nichols, J. D., Kumar, N. S., Link, W. A. and Hines, J. E. (2004) Tigers and their prey: Predicting carnivore densities from prey abundance. Proc. Natl. Acad. Sci. 101: 4854-4858.

Kawanishi, K. (2002) Population status of Tigers (Panthera tigris) in a primary rainforest of Peninsular Malaysia. Ph.D. Dissertation. Gainesville: University of Florida.

Kierulff, M. C. M., dos Santos, G. R., Canale, G., Guidorizzi, C. E. and Cassano, C. (2004) The use of camera-traps in a survey of the buff-headed capuchin monkey, Cebus xanthosternos. Neotrop. Prim. 12: 56-59.

Kinnaird, M. F., Sanderson, E. W., O'Brien, T. G., Wibisono, H. T. and Woolmer, G. (2003) Deforestation trends in a tropical landscape and implications for forest mammals. Conserv. Biol. 17: 245-257.

Kitamura, S., Suzuki, S., Yumoto, T., Poonswad, P., Chuailua, P., Plongmai, K., Noma, N., Maruhashi, T. and Suckasam, C. (2004) Dispersal of Aglaia spectabilis, a large-seeded tree species in a moist evergreen forest in Thailand. J. Trop. Ecol. 20: $421-427$.

Laidlaw, R. and Noordin, W. S. W. (1998) Activities patterns of the Indochinese Tiger (Panthera tigris corbetti) and prey species in Peninsular Malaysia. J. Wildl. Parks. 18: $85-95$.

Lambert, T. D., Malcolm, J. R. and Zimmerman, B. L. (2005) Variation in small mammal species richness by trap height and trap type in southeastern Amazon. J. Mammal. 86: 982-990. 
Leimgruber, P., McShea, W. J. and Rappole, J. H. (1994) Predation on artificial nests in large forest blocks. J. Wildl. Manage. 58: 254-260.

Liebezeit, J. R. and Luke, G. T. (2003) Comparison of mechanically egg-triggered cameras and time-lapse video cameras in identifying predators at dusky flycatcher nests. J. Field Ornith. 74: 261-269.

MacKenzie, D. I. and Nichols, J. D. (2004) Occupancy as a surrogate for abundance estimation. Anim. Biodivers. Conserv. 27: 461-467.

MacKenzie, D. I., Nichols, J. D., Lachman, G. B., Droege, S., Royle, J. A. and Langtimm, C. A. (2002) Estimating site occupancy rates when detection probabilities are less than one. Ecology 83: 2248-2255.

MacKenzie, D. I., Nichols, J. D., Hines, J. A., Knutson, M. G. and Franklin, A. D. (2003) Estimating site occupancy, colonization, and local extinction when a species is detected imperfectly. Ecology 84: 2200-2207.

MacKenzie, D. I., Nichols, J. D., Royle, J. A., Pollock, K. H., Bailey, L. L. and Hines, J. A. (2006) Occupancy estimation and modeling: Inferring patterns and dynamics of species occurrence. New York: Academic Press.

Madge, S. and McGowan, P. (2002) Pheasants, partridges and grouse: A guide to the pheasants, quails, grouse, guineafowl, buttonquails, and sandgrouse of the world. Princeton, N.J: Princeton University Press.

Malcolm, J. R. (1991) The small mammals of tropical forest fragments: Patterns and process. Ph.D. Dissertation. Gainesville: University of Florida.

Martyr, D. (1997) Important findings by FFI team in Kerenci Seblat, Sumatra, Indonesia. Oryx 31: 80-82.

Miura, S., Yasuda, M. and Ratnam, L. C. (1997) Who steals the fruits? Monitoring frugivory of mammals in a tropical forest. Malay. Nature J. 50: 183-193.

O'Brien, T. G. (in press), Abundance, density and relative abundance: A conceptual framework. O'Connell, A. F., Nichols, J. D. and Karanth, K. U., eds. Camera traps: methods and analyses. New York: Springer Verlag.
O'Brien, T. G. Kinnaird and Wibisono, H. T. (2003) Crouching tigers, hidden prey: Sumatran tiger and prey populations in a tropical forest landscape. Anim. Conserv. 6: 131-139.

O'Connell, A. F., Talancy, N. W., Bailey, L. L., Cook, R., Sauer, J. R. and Gilbert, A. T. (2006) Estimating site occupancy and detection probability parameters for mesoand large mammals in a coastal ecosystem. J. Wildl. Manage. 70: 1625-1633.

Perkins, A. J., Hancock, M. H., Butcher, N. and Summers, R. W. (2005) Use of timelapse video cameras to determine causes of nest failure of Slavonian grebes Podiceps auritus. Bird Study 52: 159-165.

Picman, J. and Schriml, L. M. (1994) A camera study of temporal patterns of nest predation in different habitats. Wilson Bull. 106: 456-465.

Pietz, P. J. and Granfors, D. A. (2005) Parental nest defense on videotape: More reality than "myth". Auk 122: 701-705.

Purcell, K. L. and Verner, J. (1999) Nest predators of open and cavity nesting birds in oak woodlands. Wilson Bull. 111: 251-256.

Robbins, C. S., Bystrak, B. A. and Geissler, P. H. (1986) The breeding bird survey: Its first fifteen years (1965-1979). Washington DC: USDOI, Fish and Wildlife Service Publication 157.

Rovero, F. and Marshall, A. R. (2004) Estimating the abundance of forest antelopes by line transect techniques: A case from the Udzungwa Mountains of Tanzania. Trop. Zool. 17: 267-277.

Rowcliffe, J. M., Field, J., Turvey, S. T. and Carbone, C. (2008) A new application for camera traps: estimating the density of unmarked animals. J. Appl. Ecol. doi:10.1111/j.1365-2664.2008.01473.x.

Royle, J. A. (2004) N-mixture models for estimating population size from spatially replicated counts. Biometrics 60: 108-115.

Royle, J. A. and Nichols, J. D. (2003) Estimating abundance from repeated presence-absence data or point counts. Ecology 84: 777-79o.

Sanderson, J. G. and Trolle, M. (2005) Monitoring elusive mammals: Unattended cameras reveal secrets of some of the world's wildest places. Amer. Scient. 93: 148-155. 
Seber, G. A. F. (1982) The estimation of animal abundance and related parameters. New York: Macmillan.

Silveira, L., Jácomo, A. T. A. and Diniz-Filho, J. A. F. (2003) Camera trap, line transect census and track surveys: a comparative evaluation. Biol. Conserv. 114: 351-355.

Smith, M. L. (2004) Edge effects on nest predators in two forested landscapes. Can. J. Zool. 82: 1943-1953.

Stephens, P. A., Zaumyslova, O. Y., Miquelle, D. G., Myslenov, A. I. and Hayward, G. D. (2006) Estimating population density from indirect sign: track counts and the Formozov-Malyshev-Pereleshin formula. Anim. Conserv. 9: 339-348.

Thompson, F. R. III and Burhans, D. E. (2003) Predation of songbird nests differs by predator and between field and forest habitats. J. Wildl. Manage. 67: 408-416.

van Schaik, C. P. and Griffiths, M. (1996) Activity periods of Indonesian rain forest mammals. Biotropica 28: 105-112.

Wegge, P., Pokheral, C. P. and Jnawali, S. J. (2004) Effects of trapping effort and trap shyness on estimates of abundance from camera trap studies. Anim. Cons. 7: $251-256$.

White, G. C. (1993) Evaluation of radiotagging marking and sighting estimators of population size using Monte Carlo simulations. Pp. 91-103 in J. D. Lebreton and P. M. North, eds. The study of bird population dynamics using marked individuals. New York: Columbia University Press.

Wibisono, H. T. (2006) Population ecology of Sumatran Tigers (Panthera tigrus sumatrae) and their prey in Bukit Barisan Selatan National Park, Sumatra, Indonesia. Unpubl. M.Sc. Thesis. Amherst: University of Massachusetts.

Williams, B. K., Nichols, J. D. and Conroy, M. J. (2002) Analysis and management of animal populations. New York: Academic Press.

Winarni, N. L. (2002) Distribution and movement patterns of Great Argus Pheasant (Argusianus argus) in Bukit Barisan Selatan, Sumatra, Indonesia. Unpubl. M.Sc. Thesis. Athens: University of Georgia.

Winarni, N. L., Nurcahyo, A., Hadiprakarsa, Y. and Iqbal, M. (2005) Effects of forest patch size on Galliformes in southern Sumatra, Indonesia. Pp. 57-68 in R. A. Fuller and S. J. Browne, eds. Galliformes 2004. Proceedings of the 3 rd International Galliformes Symposium. Fordingbridge, UK: World Pheasant Association.

Winarni, N. L., O'Brien, T. G., Carroll, J. P. and Kinnaird, M. F. (in review) Movements, distribution and abundance of Great Argus Pheasants (Argusianus argus) in a Sumatran rainforest. Submitted to $A u k$.

Zegers, D. A., May, S. and Goodrich, L. J. (2000) Identification of nest predators at farm/forest edge and forest interior sites. J. Field Ornith. 71: 207-216.

Zetra, B. A. Rafiastanto, Rombang, W. M. and Trainor, C. R. (2002) Rediscovery of the critically endangered Sumatran Ground Cuckoo Carpococcyx viridis. Forktail 18 : $63-65$.

\section{TIMOTHY G. O'BRIEN*, MARGARET F. KINNAIRD}

Wildlife Conservation Society, 2300 Southern Blvd, Bronx, NY 10460, U.S.A., and Mpala Research Centre, P.O. Box 555, Nanyuki, Kenya.

* Author for correspondence; e-mail: tobrien@wcs.org 